\title{
Mammary inflammation around parturition appeared to be attenuated by consumption of fish oil rich in n-3 polyunsaturated fatty acids
}

Sen Lin ${ }^{\dagger}$, Jia Hou ${ }^{\dagger}$, Fang Xiang ${ }^{\dagger}$, Xiaoling Zhang, Lianqiang Che, Yan Lin, Shengyu Xu, Gang Tian, Qiufeng Zeng, Bing Yu, Keying Zhang, Daiwen Chen, De Wu and Zhengfeng Fang*

\begin{abstract}
Background: Mastitis endangers the health of domestic animals and humans, and may cause problems concerning food safety. It is documented that n-3 polyunsaturated fatty acids (PUFA) play significant roles in attenuating saturated fatty acids (SFA)-induced inflammation. This study was therefore conducted to determine whether mammary inflammation could be affected by consumption of diets rich in n-3 PUFA.

Methods: Forty-eight rats after mating began to receive diets supplemented with 5\% fish oil (FO) or $7 \%$ soybean oil (SO). Blood and mammary tissue samples $(n=6)$ at day 0 and 14 of gestation and day 3 postpartum were collected 9 hours after intramammary infusion of saline or lipopolysaccharide (LPS) to determine free fatty acids (FFA) concentration and FA composition in plasma and inflammation mediators in mammary tissues.

Results: At day 14 of gestation and day 3 postpartum, the FO-fed rats had lower plasma concentrations of C18:2n6, C20:4n6, total n-6 PUFA and SFA, and higher plasma concentrations of C20:5n3 and total n-3 PUFA than the SO-fed rats. Plasma C22:6n3 concentration was also higher in the FO-fed than in the SO-fed rats at day 3 postpartum. Compared with the SO-fed rats, the FO-fed rats had lower mammary mRNA abundance of xanthine oxidoreductase (XOR) and protein level of tumor necrosis factor (TNF)-a, but had higher mammary mRNA abundances of interleukin (IL)-10 and peroxisome proliferator-activated receptor (PPAR)- $\gamma$ at day 14 of gestation. Following LPS infusion at day 3 postpartum, the SO-fed rats had increased plasma concentrations of FFA, C18:1n9, C18:3n3, C18:2n6 and total n-6 PUFA, higher mammary mRNA abundances of IL-1 $\beta$, TNF- $\alpha$ and XOR but lower mammary mRNA abundance of IL-10 than the FO-fed rats.
\end{abstract}

Conclusions: Mammary inflammation around parturition appeared to be attenuated by consumption of a diet rich in n-3 PUFA, which was associated with up-regulated expression of IL-10 and PPAR- $\gamma$.

Keywords: Mastitis, n-3 PUFA, Inflammatory cytokines, IL-10, PPAR- $\gamma$

\section{Background}

Udder health is pivotal to productivity, antibiotic use and animal welfare [1]. Mastitis threatens the health of mammals all over the world including humans. For the dairy industry, mastitis is the most costly common disease, and the economic loss due to mastitis in dairy

\footnotetext{
* Correspondence: fangzhengfeng@hotmail.com

${ }^{\dagger}$ Equal contributors

Key Laboratory for Animal Disease Resistance Nutrition of the Ministry of

Education of China, Animal Nutrition Institute, Sichuan Agricultural University, Sichuan, Ya'an 625014, China
}

cattle is estimated at $\$ 185 /$ cow/year in the United States [2]. For the pork industry, the infection of the mammary glands results in reduced productivity of sows and increased mortality of piglets [3]. Up to a third of lactating women will become ill because of mastitis [4]. The occurrence of mastitis is characterized by redness, swelling, and pain. However, without these symptoms, subclinical mastitis can also endanger the health of mammals, characterized by a high somatic cell count [5]. Owing to its invisible characteristic, subclinical mastitis may be neglected and bring even larger economic 
loss. The current method to treat mastitis is to use antibiotics [6], which may lower the quality of animal products, and threaten the health of humans. Thus, new methods dealing with clinical and subclinical mastitis are urgently needed.

It is generally considered that exogenous pathogens are the main causes of mastitis, as E.coli and staphylococcus have been confirmed to play key roles in inducing mastitis in domestic animals [6,7]. These microorganisms may activate the mammary innate immune systems and thus cause inflammatory responses. Lipopolysaccharide (LPS) has been used as the agonist in construction of mastitis models in vivo and in vitro $[7,8]$. Recent studies indicated that in addition to LPS, saturated fatty

Table 1 Plasma FA composition $\left(\mu \mathrm{g} / \mathrm{mL}\right.$ ) of rats fed different diets at different reproductive stages ${ }^{1}$

\begin{tabular}{|c|c|c|c|c|c|}
\hline Item & Group & Day 0 of gestation & Day 14 of gestation & Day 3 postpartum & Pooled SEM \\
\hline \multirow[t]{2}{*}{ C14:0 } & SO & $30.69^{a}$ & $28.54^{\mathrm{ab}}$ & $32.62^{a}$ & 13.69 \\
\hline & $\mathrm{FO}$ & $14.35^{b}$ & $18.22^{\mathrm{ab}}$ & $21.11^{\mathrm{ab}}$ & \\
\hline \multirow[t]{2}{*}{ C16:0 } & so & $822.89^{a}$ & $738.64^{a b}$ & $948.69^{a}$ & 249.21 \\
\hline & $\mathrm{FO}$ & $432.50^{c}$ & $455.61^{\mathrm{bc}}$ & $373.53^{c}$ & \\
\hline \multirow[t]{2}{*}{ C18:0 } & so & $588.93^{\mathrm{a}}$ & $526.74^{\mathrm{a}}$ & $688.14^{\mathrm{a}}$ & 152.56 \\
\hline & FO & $342.09^{b}$ & $311.58^{\mathrm{b}}$ & $239.47^{\mathrm{b}}$ & \\
\hline \multirow[t]{2}{*}{ C20:0 } & SO & $21.42^{\mathrm{a}}$ & $10.30^{b}$ & $13.32^{\mathrm{ab}}$ & 8.91 \\
\hline & FO & $6.33^{b}$ & $6.71^{b}$ & $4.17^{\mathrm{b}}$ & \\
\hline \multirow[t]{2}{*}{ SFA } & SO & $1463.92^{\mathrm{a}}$ & $1304.23^{\mathrm{a}}$ & $1682.78^{\mathrm{a}}$ & 412.54 \\
\hline & $\mathrm{FO}$ & $795.28^{b}$ & $792.12^{\mathrm{b}}$ & $638.28^{b}$ & \\
\hline \multirow[t]{2}{*}{ C16:1 } & SO & $59.10^{\mathrm{a}}$ & $47.62^{\mathrm{ab}}$ & $57.58^{\mathrm{a}}$ & 23.81 \\
\hline & $\mathrm{FO}$ & $42.06^{\mathrm{ab}}$ & $42.55^{\mathrm{ab}}$ & $20.74^{b}$ & \\
\hline \multirow[t]{2}{*}{ C18:1n7 } & so & $27.86^{\mathrm{ab}}$ & $23.04^{b}$ & $42.41^{\mathrm{a}}$ & 14.47 \\
\hline & $\mathrm{FO}$ & $23.01^{b}$ & $20.98^{b}$ & $22.75^{b}$ & \\
\hline \multirow[t]{2}{*}{ C18:1n9 } & SO & 191.83 & 177.43 & 156.96 & 40.63 \\
\hline & $\mathrm{FO}$ & 198.23 & 203.30 & 162.35 & \\
\hline \multirow[t]{2}{*}{ C20:1 } & so & $30.67^{\mathrm{ab}}$ & $26.84^{\mathrm{abc}}$ & $40.99^{a}$ & 15.54 \\
\hline & FO & $10.95^{\mathrm{cd}}$ & $12.91^{\mathrm{bcd}}$ & $5.41^{d}$ & \\
\hline \multirow[t]{2}{*}{ MUFA } & so & 309.46 & 274.93 & 297.94 & 86.48 \\
\hline & $\mathrm{FO}$ & 274.25 & 279.74 & 211.26 & \\
\hline \multirow[t]{2}{*}{ C18:3n3 } & SO & $8.99^{\mathrm{abc}}$ & $10.82^{\mathrm{ab}}$ & $11.65^{\mathrm{a}}$ & 1.84 \\
\hline & $\mathrm{FO}$ & $7.07^{\mathrm{bc}}$ & $8.42^{\mathrm{abc}}$ & $6.43^{c}$ & \\
\hline \multirow[t]{2}{*}{ C20:5n3 } & SO & $7.59^{b}$ & $5.32^{\mathrm{b}}$ & $8.00^{b}$ & 22.64 \\
\hline & $\mathrm{FO}$ & $26.62^{b}$ & $87.73^{\mathrm{a}}$ & $95.75^{\mathrm{a}}$ & \\
\hline \multirow[t]{2}{*}{ C22:6n3 } & so & $40.45^{b}$ & $37.53^{b}$ & $76.60^{b}$ & 36.39 \\
\hline & $\mathrm{FO}$ & $73.89^{b}$ & $63.54^{b}$ & $146.34^{\mathrm{a}}$ & \\
\hline \multirow[t]{2}{*}{ n-3 PUFA } & so & $64.84^{c}$ & $54.74^{c}$ & $96.25^{c}$ & 50.47 \\
\hline & $\mathrm{FO}$ & $107.58^{b c}$ & $159.69^{b}$ & $248.51^{\mathrm{a}}$ & \\
\hline \multirow[t]{2}{*}{ C18:2n6 } & SO & $253.41^{a}$ & $230.13^{a}$ & $262.59^{\mathrm{a}}$ & 45.26 \\
\hline & $\mathrm{FO}$ & $235.76^{\mathrm{a}}$ & $163.29^{\mathrm{b}}$ & $169.54^{b}$ & \\
\hline \multirow[t]{2}{*}{ C20:4n6 } & SO & $257.71^{b}$ & $233.28^{\mathrm{b}}$ & $400.24^{\mathrm{a}}$ & 87.69 \\
\hline & $\mathrm{FO}$ & $246.19^{b}$ & $116.03^{c}$ & $197.67^{\mathrm{bc}}$ & \\
\hline \multirow[t]{2}{*}{ n-6 PUFA } & SO & $511.12^{b}$ & $463.41^{b c}$ & $662.83^{\mathrm{a}}$ & 119.17 \\
\hline & $\mathrm{FO}$ & $481.95^{b c}$ & $279.31^{d}$ & $367.21^{\mathrm{cd}}$ & \\
\hline \multirow[t]{2}{*}{ TFA } & $\mathrm{SO}$ & $2349.34^{\mathrm{ab}}$ & $2097.31^{a b c}$ & $2739.80^{a}$ & 557.06 \\
\hline & FO & $1704.65^{b c}$ & $1510.87^{c}$ & $1465.26^{c}$ & \\
\hline
\end{tabular}

${ }^{1}$ Values of a certain fatty acid assigned no common superscript letter differ significantly $(P<0.05)$. 


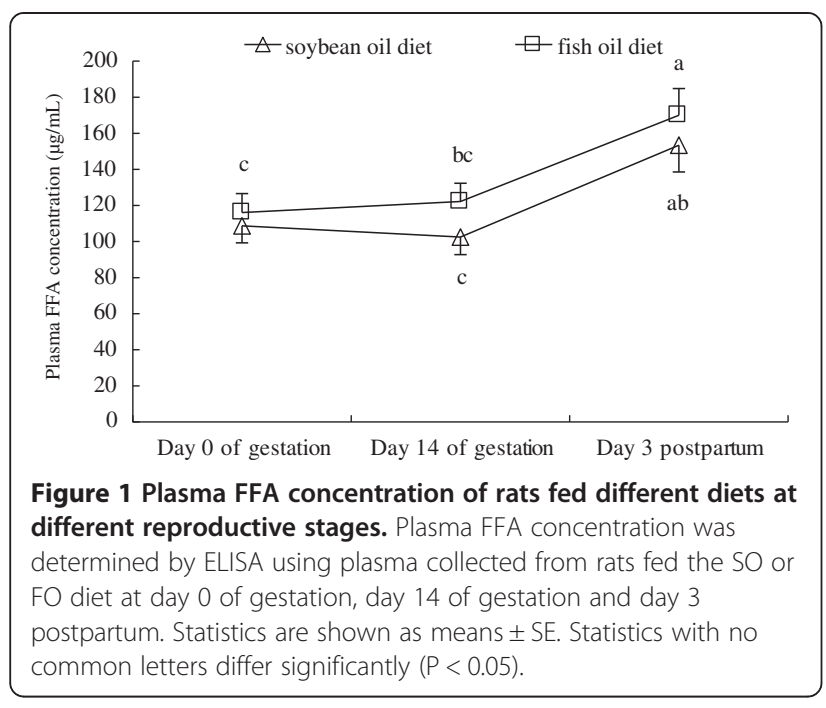

acids (SFA) could also activate Toll-like-receptor (TLR) 4 signaling pathway through regulation of receptor dimerization and recruitment into lipid rafts in a reactive oxygen species (ROS)-dependent manner [9]. Further studies revealed that the cooperative effect of SFA and LPS on monocytes resulted in about 3-fold higher mRNA and protein expression of pro-inflammatory cytokines than the sum of individual responses to SFA and LPS, indicating nutrient modification of TLR4mediated inflammation [10]. It was reported that SFA were enriched in milk of mice fed western diet, and triggered ceramide accumulation and inflammation in the neonates [11]. Notably, the neonatal toxicity requires TLR but not microbiota [11], suggesting that SFA may induce inflammatory responses independent of exogenous pathogens. Studies in vivo and in vitro have demonstrated that $\mathrm{n}-3$ polyunsaturated fatty acids (PUFA) could block SFA- and/or LPS-induced TLR signalling and attenuate inflammation [12]. However, little is known about whether the mammary inflammation induced by nutrients such as SFA and pathogens such as LPS could be attenuated by consumption of diets rich in n-3 PUFA.

Therefore, the objectives of the present study were to evaluate the interactive effect of diets and reproductive stages on fatty acids (FA) metabolism and inflammation as well as to determine the effect of dietary n-3 PUFA on plasma FA composition and mammary glands inflammation.
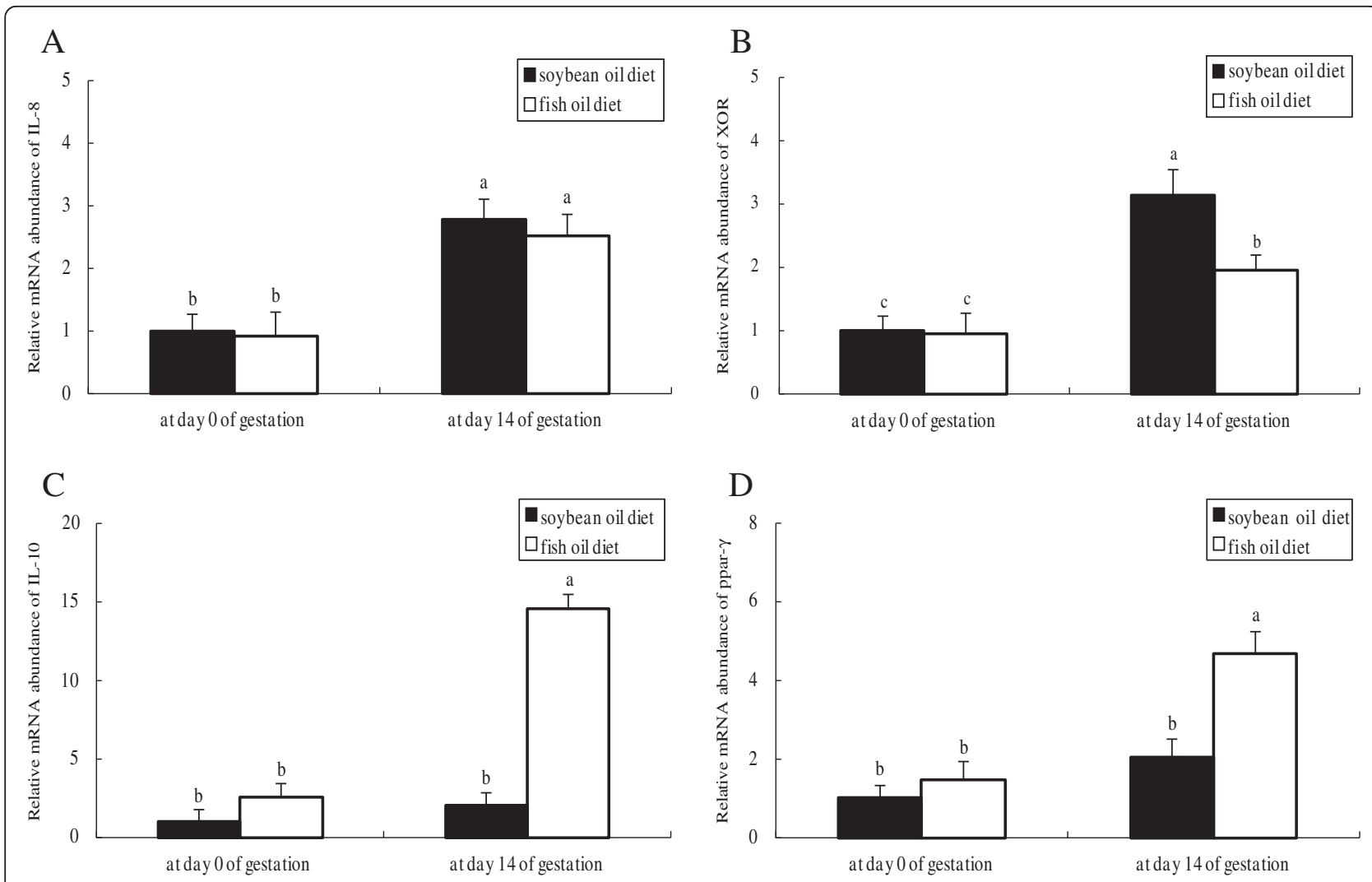

Figure 2 Relative mRNA abundances of rats fed different diets at different reproductive stages. mRNA abundances of IL-8 (A), XOR (B), IL-10 (C) and PPAR-Y (D) was determined by RT-PCR with mammary tissues collected from rats fed the SO or FO diet at day 0 and 14 of gestation. Statistics are shown as means \pm SE. Statistics with no common letters differ significantly $(P<0.05)$. 


\section{Results}

Effect of diet type on plasma FA composition at different reproductive stages

Consumption of the SO diet increased plasma concentrations of C20:4n6 and total n- 6 PUFA at day 3 postpartum (Table 1). In contrast, consumption of the FO diet increased plasma concentrations of C20:5n3 from day 14 of gestation and $\mathrm{C} 22: 6 \mathrm{n} 3$ at day 3 postpartum. Compared with the SO-fed rats, the FO-fed rats had lower plasma concentration of C16:0 at day 0 of gestation and day 3 postpartum, concentrations of C18:2n6, C20:4n6 and total n-6 PUFA at day 14 of gestation and day 3 postpartum, and concentrations of C18:0 and total SFA at the three time points evaluated, but had higher plasma concentration of C22:6n3 at day 3 postpartum, and concentrations of $\mathrm{C} 20: 5 \mathrm{n} 3$ and total n-3 PUFA at day 14 of gestation and day 3 postpartum.

\section{Effect of reproductive stages and diet type on plasma FFA concentration and inflammation mediators in rat mammary glands}

Plasma FFA concentration in both groups was higher at day 3 postpartum than at day 0 and 14 of gestation, with no difference observed between groups at each of the time points evaluated (Figure 1). In both groups, the mRNA abundances of IL-8 and xanthine oxidoreductase (XOR) (Figure 2), the protein levels of IL-1 $\beta$ (Figure 3 ) and TNF- $\alpha$ (Figure 4) as well as PMN prevalence (Figure 5) were higher at day 14 of gestation than at day 0 of gestation. Compared with the SO-fed rats, the FO-fed rats had lower mammary mRNA abundance of XOR (Figure 2)

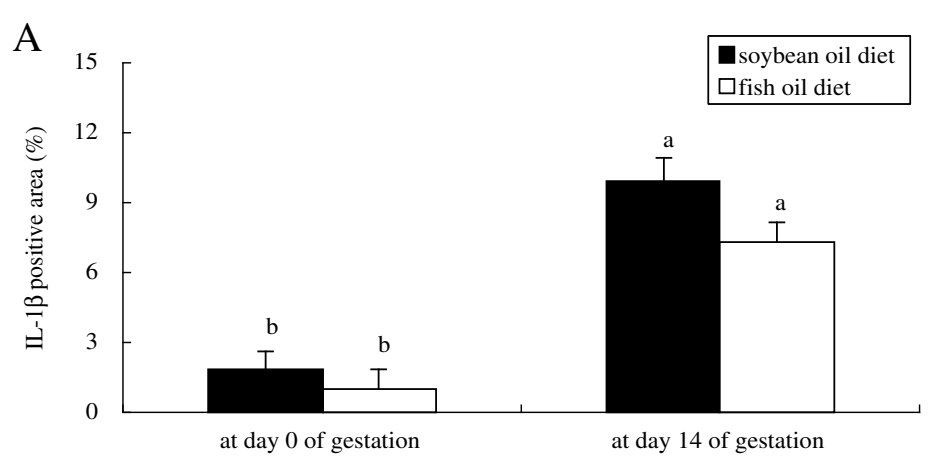

$\mathrm{B}$

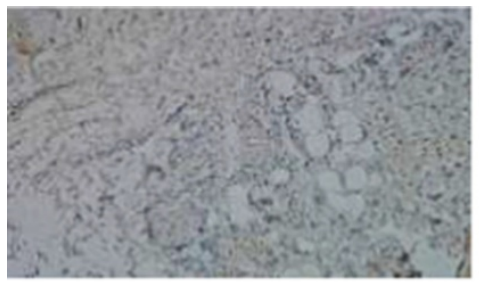

day 0 of gestation

$\mathrm{C}$

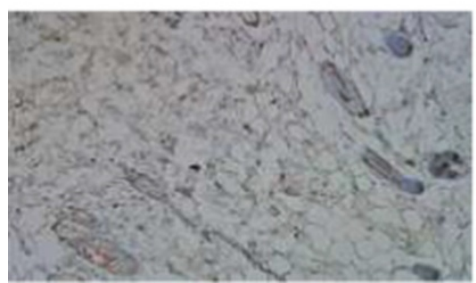

day 0 of gestation

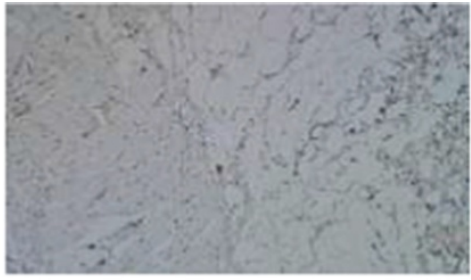

day 14 of gestation

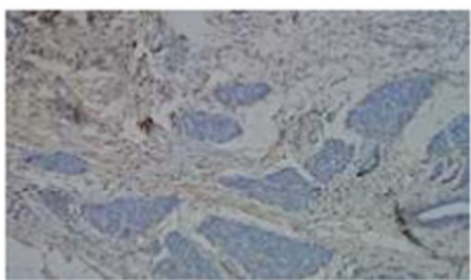

day 14 of gestation

Figure 3 Immunohistochemical localization of IL-1 $\beta$ in udder of rats fed different diets at different reproductive stages. The microphotograph from one rat with the positive primary IL-1 $\beta$ antibody was visualized with $D A B$ reaction. The area positive for IL-1 $\beta$ in mammary tissues of rats fed the SO diet (B) or FO diet (C) at day 0 and 14 of gestation was quantified by Easy Image 3000 software. IL-1 $\beta$ production is presented as the average percentage of the positively stained areas (A). Statistics are shown as means \pm SE. Statistics with no common letters differ significantly $(P<0.05)$. 


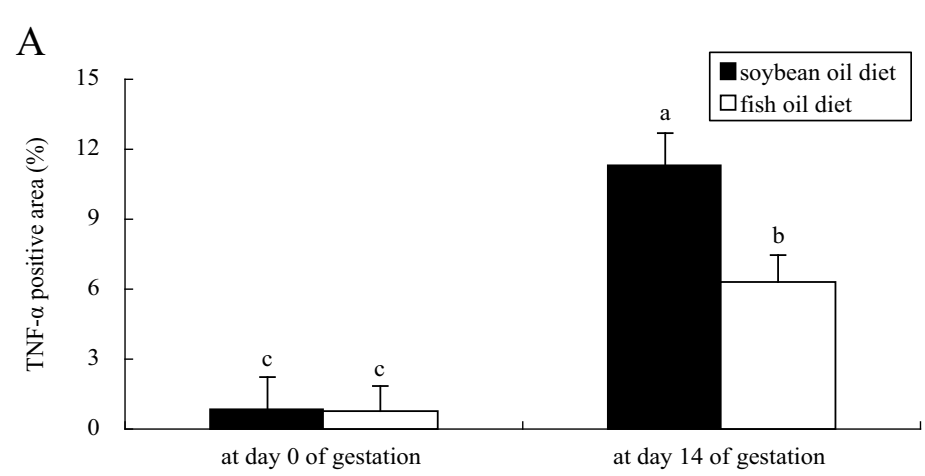

$\mathrm{B}$

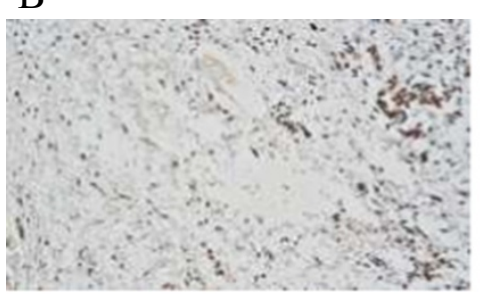

day 0 of gestation

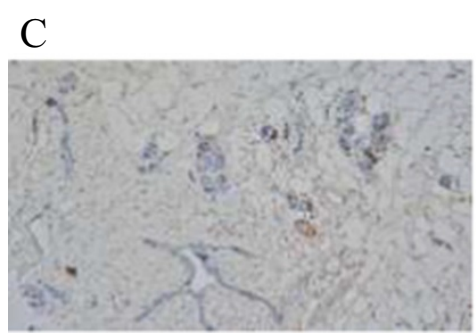

day 0 of gestation

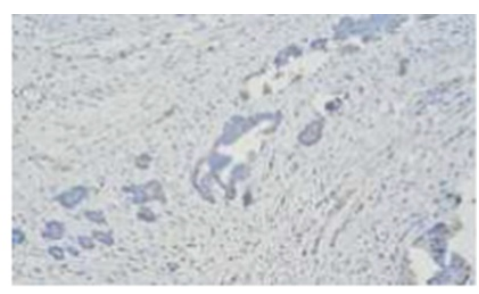

day 14 of gestation

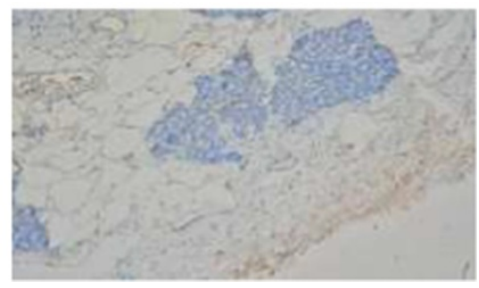

day 14 of gestation

Figure 4 Immunohistochemical localization of TNF- $a$ in udder of rats fed different diets at different reproductive stages. The microphotograph from one rat with the positive primary TNF-a antibody was visualized with DAB reaction. The area positive for TNF-a in mammary tissues of rats fed the SO diet (B) or FO diet (C) at day 0 and14 of gestation was quantified by Easy Image 3000 software. TNF-a production is presented as the average percentage of the positively stained areas (A). Statistics are shown as means \pm SE. Statistics with no common letters differ significantly $(P<0.05)$.

and protein level of TNF- $\alpha$ (Figure 4), but had higher mammary mRNA abundances of IL-10 and peroxisome proliferator-activated receptor (PPAR)- $\gamma$ at day 14 of gestation (Figure 2).

\section{Effect of LPS infusion and diet type on plasma FFA concentration and plasma FA composition}

Following LPS infusion at day 3 postpartum, both groups had increased plasma FFA concentration with no difference observed between them (Figure 6). LPS infusion resulted in increased plasma concentrations of C18:1n9, C18:3n3, C18:2n6 and total n-6 PUFA in the SO-fed rats, whereas no change was observed in the FO-fed rats. As a result, the FO-fed rats still had higher plasma concentrations of C20:5n3, C22:6n3 and total n-3 PUFA, and lower plasma concentrations of C18:2n6, C20:4n6, total n-6 PUFA, SFA and FA than the SO-fed rats following LPS infusion (Table 2).

\section{Effect of diet type on inflammation mediators in LPS-infused mammary glands}

Mammary mRNA abundances of IL-1 $\beta$, TNF- $\alpha$ and $\mathrm{XOR}$ (Figure 7) as well as PMN prevalence (Figure 8) were increased following LPS infusion at day 3 postpartum, which was observed in the SO-fed rats rather than in the FO-fed rats. Accordingly, mammary mRNA abundances of IL-1 $\beta$, TNF- $\alpha$ and XOR following LPS infusion was lower in the FO-fed than in the SO-fed rats (Figure 7). In contrast, mammary IL-10 mRNA abundance was higher in the FO-fed than in the SO-fed rats, although it was decreased in the FO-fed rats following LPS challenge (Figure 7). 


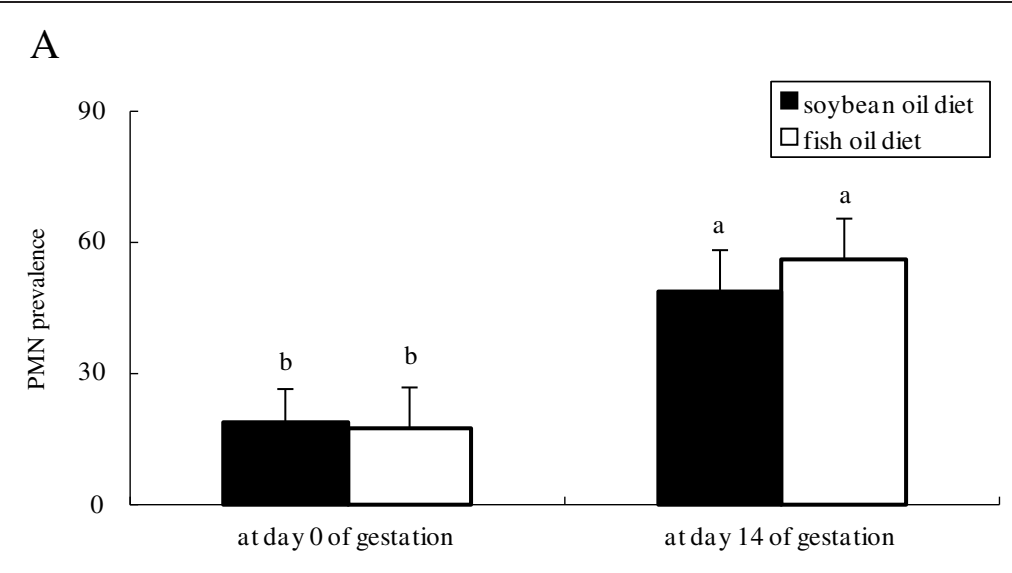

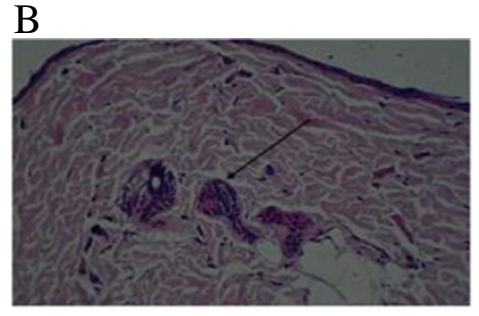

day 0 of gestation

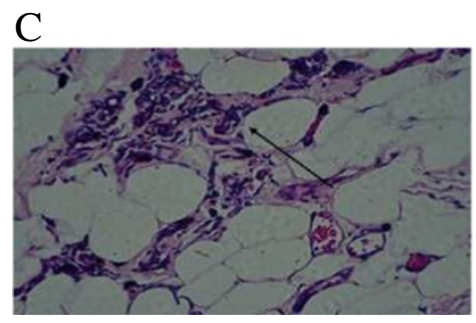

day 0 of gestation

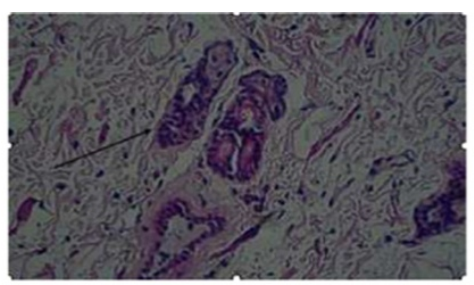

day 14 of gestation

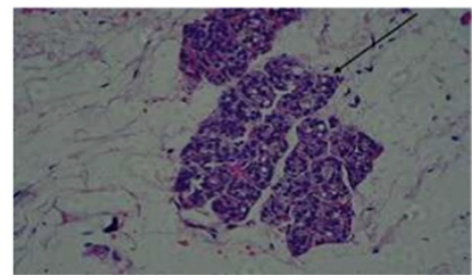

day 14 of gestation

Figure $\mathbf{5}$ Histopathology of mammary glands of rats fed different diets at different reproductive stages. Hematoxylin and eosin stained slides were made with mammary tissues collected from rats fed the SO diet (B) or FO diet (C) at day 0 and 14 of gestation. PMN prevalence (A) in alveoli was estimated by using light microscopic (Olympus $\mathrm{BH}$ 2, Japan) analysis at a magnification of $400 \times$. Statistics are shown as means $\pm \mathrm{SE}$. Statistics with no common letters differ significantly $(P<0.05)$.

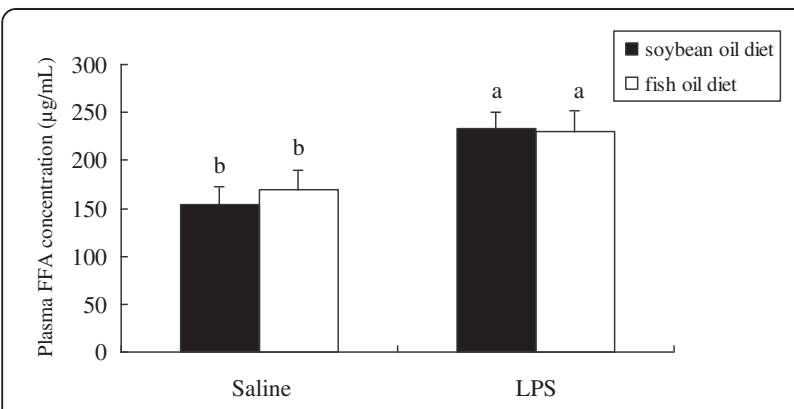

Figure 6 Plasma FFA concentration of rats fed different diets and challenged with different stimulus. Plasma FFA concentration was determined by ELISA using plasma collected from rats fed the SO or FO diet and challenged with saline or LPS. Statistics are shown as means \pm SE. Statistics with no common letters differ significantly $(P<0.05)$.

\section{Discussion}

The beneficial effects of FO have been documented abundantly [13-15]. And evidences concerning n-3 PUFA alleviating inflammation were persuasive [16-18]. However, the effect of dietary FO on attenuating mammary inflammation has not been verified. Thus, the present study was focused on the mammary glands to test the antiinflammatory effect of dietary FO.

Given that inflammatory responses are in strong association with FA types such as n-6 and n-3 PUFA, we firstly examined the plasma FA profile at different reproductive stages of rats receiving different diets. An amplified plasma concentration of n-3 PUFA was observed following FO consumption for 14 days in this study, which agreed well with the previous study in horses by 
Table 2 Plasma FA composition $(\mu \mathrm{g} / \mathrm{mL})$ of rats fed different diets and challenged with different stimulus

\begin{tabular}{llllll}
\hline Item $^{1}$ & SS & SL & FS & FL & Pooled SEM \\
\hline C14:0 & $32.62^{\mathrm{ab}}$ & $45.60^{\mathrm{a}}$ & $21.11^{\mathrm{b}}$ & $20.19^{\mathrm{b}}$ & 13.95 \\
C16:0 & $948.69^{\mathrm{a}}$ & $1103.10^{\mathrm{a}}$ & $373.53^{\mathrm{b}}$ & $581.32^{\mathrm{b}}$ & 231.72 \\
C18:0 & $688.14^{\mathrm{a}}$ & $791.68^{\mathrm{a}}$ & $239.47^{\mathrm{b}}$ & $401.64^{\mathrm{b}}$ & 138.39 \\
C20:0 & $13.32^{\mathrm{ab}}$ & $17.10^{\mathrm{a}}$ & $4.17^{\mathrm{c}}$ & $8.11^{\mathrm{bc}}$ & 4.04 \\
SFA & $1682.78^{\mathrm{a}}$ & $1957.48^{\mathrm{a}}$ & $634.11^{\mathrm{b}}$ & $1003.14^{\mathrm{b}}$ & 382.43 \\
C16:1 & $57.58^{\mathrm{ab}}$ & $80.16^{\mathrm{a}}$ & $20.74^{\mathrm{c}}$ & $43.88^{\mathrm{bc}}$ & 23.12 \\
C18:1n7 & $42.41^{\mathrm{b}}$ & $51.73^{\mathrm{a}}$ & $22.75^{\mathrm{b}}$ & $21.87^{\mathrm{b}}$ & 19.09 \\
C18:1n9 & $156.96^{\mathrm{b}}$ & $218.23^{\mathrm{a}}$ & $162.35^{\mathrm{b}}$ & $195.47^{\mathrm{ab}}$ & 36.77 \\
C20:1 & $40.99^{\mathrm{ab}}$ & $55.48^{\mathrm{a}}$ & $5.41^{\mathrm{c}}$ & $21.85^{\mathrm{bc}}$ & 18.35 \\
MUFA & $297.94^{\mathrm{ab}}$ & $405.60^{\mathrm{a}}$ & $211.26^{\mathrm{b}}$ & $283.07^{\mathrm{ab}}$ & 86.41 \\
C18:3n3 & $11.65^{\mathrm{b}}$ & $21.24^{\mathrm{a}}$ & $6.43^{\mathrm{b}}$ & $8.32^{\mathrm{b}}$ & 4.67 \\
C20:5n3 & $8.00^{\mathrm{b}}$ & $11.32^{\mathrm{b}}$ & $95.75^{\mathrm{a}}$ & $142.18^{\mathrm{a}}$ & 41.03 \\
C22:6n3 & $76.60^{\mathrm{c}}$ & $96.50^{\mathrm{bc}}$ & $146.34^{\mathrm{ab}}$ & $161.66^{\mathrm{a}}$ & 32.93 \\
n-3PUFA & $96.25^{\mathrm{b}}$ & $129.05^{\mathrm{b}}$ & $248.51^{\mathrm{a}}$ & $312.16^{\mathrm{a}}$ & 59.83 \\
C18:2n6 & $262.59^{\mathrm{b}}$ & $379.98^{\mathrm{a}}$ & $169.54^{\mathrm{c}}$ & $202.36^{\mathrm{bc}}$ & 53.52 \\
C20:4n6 & $400.24^{\mathrm{a}}$ & $485.86^{\mathrm{a}}$ & $197.67^{\mathrm{b}}$ & $206.75^{\mathrm{b}}$ & 79.46 \\
n-6PUFA & $662.83^{\mathrm{b}}$ & $865.84^{\mathrm{a}}$ & $367.21^{\mathrm{c}}$ & $409.11^{\mathrm{c}}$ & 117.17 \\
TFA & $2739.80^{\mathrm{ab}}$ & $3357.97^{\mathrm{a}}$ & $1465.26^{\mathrm{c}}$ & $2015.59^{\mathrm{bc}}$ & 519.16 \\
\hline
\end{tabular}

${ }^{\mathrm{abc}}$ Values in the same row assigned no common superscript letter differ significantly $(P<0.05)$.

${ }^{1} \mathrm{SS}$, rats fed the SO diet and infused by saline; SL, rats fed the SO diet and infused by LPS; FS, rats fed the FO diet and infused by saline; FL, rats fed the FO diet and infused by LPS

Hall et al [19]. Hall et al [19] also found decreased plasma n-6 FA concentration in the FO-fed horses, but little variation of plasma n-6 PUFA concentration was observed in the FO-fed rats in this study. Noting that the horses used in the study of Hall et al [19] consumed FO for 6 weeks, a shorter consumption period (24 days) in this study may explain the little variation of $n-6$ PUFA. In addition, it was verified in the present study that substituting $\mathrm{SO}$ with $\mathrm{FO}$ resulted in higher plasma n-3 PUFA concentration and lower concentrations of SFA and n-6 PUFA. Amira et al [20] reported that decreased $n-6 / n-3$ ratio led to higher plasma $n-3$ PUFA concentration and lower n-6 PUFA concentration, which was consistent with our results considering that the $n-6 /$ $\mathrm{n}-3$ ratio in our experimental diets was approximately $0.5: 1$ in the FO diet and 10:1 in the SO diet.

Another result in the present study was that upregulated plasma FFA emerged with the advance of gestation. As FFA have been reported to be associated with inflammation including mastitis [20,21], we further studied whether the advance of gestation was related to the expression of inflammation mediators. In both diet groups, the mRNA abundances of XOR and IL-8, protein levels of IL-1 $\beta$ and TNF- $\alpha$ as well as PMN prevalence all increased from day 0 of gestation to day 14 of gestation. TNF- $\alpha$, IL- 8 and IL- $1 \beta$ are all known as pro-inflammatory cytokines. Stimulated by a range of agents, TNF- $\alpha$ induces other inflammatory mediators that participated in inflammatory responses [22]. IL-8 can activate neutrophils to degranulate and induce tissue damage [23]. Moreover, IL- $1 \beta$ and TNF- $\alpha$ were elucidated to be key mediators participating in the neutrophil recruitment into the udder [24]. XOR is also an inflammatory indicator that highly expressed in mammary tissues during pregnancy and lactation $[25,26]$. Hence, we proposed that the advance of pregnancy was accompanied by inflammatory responses of the udder. Notably, compared with the SO-fed rats, the FO-fed rats had lower mRNA levels of XOR and TNF- $\alpha$ but higher mRNA levels of IL-10 and PPAR- $\gamma$, both of which are acknowledged as antiinflammatory mediators $[27,28]$. The down-regulation of XOR and TNF- $\alpha$ may be induced by the lower SFA and n-6 PUFA concentrations and higher n-3 PUFA concentrations in plasma. Consistent with this notion, it has been shown that the decreased production of TNF was accompanied by a decreased ratio of C20:4n6 to C20:5n3 in the membrane phospholipids of mononuclear cells, which indicates the significance of systemic n-6/n-3 PUFA profile in inflammatory responses [29].

Excited by the potential effect of FO in decreasing pro-inflammatory cytokines in mammary glands, we further determined the anti-inflammatory effect of FO with a rat mastitis model. Rats at day 3 postpartum were infused with LPS or saline. LPS challenge resulted in elevated plasma FFA in both groups indicating the systemic inflammation induced by LPS. However, only in the SO-fed rats did LPS infusion stimulate the expression of IL- $1 \beta$, XOR and TNF- $\alpha$. During the process of mammary glands inflammation induced by advance of gestation as well as by LPS infusion, the relatively lower level of mammary pro-inflammatory mediators in the FO-fed rats may result from higher total n-3 PUFA concentration and lower SFA concentration in plasma. During lactation, the mammary blood flow increased sharply [30] and the mammary glands may become more susceptible to substances in the blood. Therefore, we assumed that the relatively higher SFA concentration in the SO-fed rats may lead to aggravated toxicity of LPS. On one hand, LPS could activate the TLR4 pathway, free NF-kB [31] and finally facilitate the expression of pro-inflammatory cytokines in the mammary glands of the SO-fed rats. On the other hand, the elevated XOR expression may enhance the generation of ROS which may participate in the TLR4 dimerization and recruitment of TLR4 into lipid rafts on condition that SFA were metabolized into ceramide $[9,10]$. The higher levels of PPAR- $\gamma$ and IL-10 in the FO-fed rats may block the TLR4 pathway, as elucidated previously $[32,33]$. It has been demonstrated that 


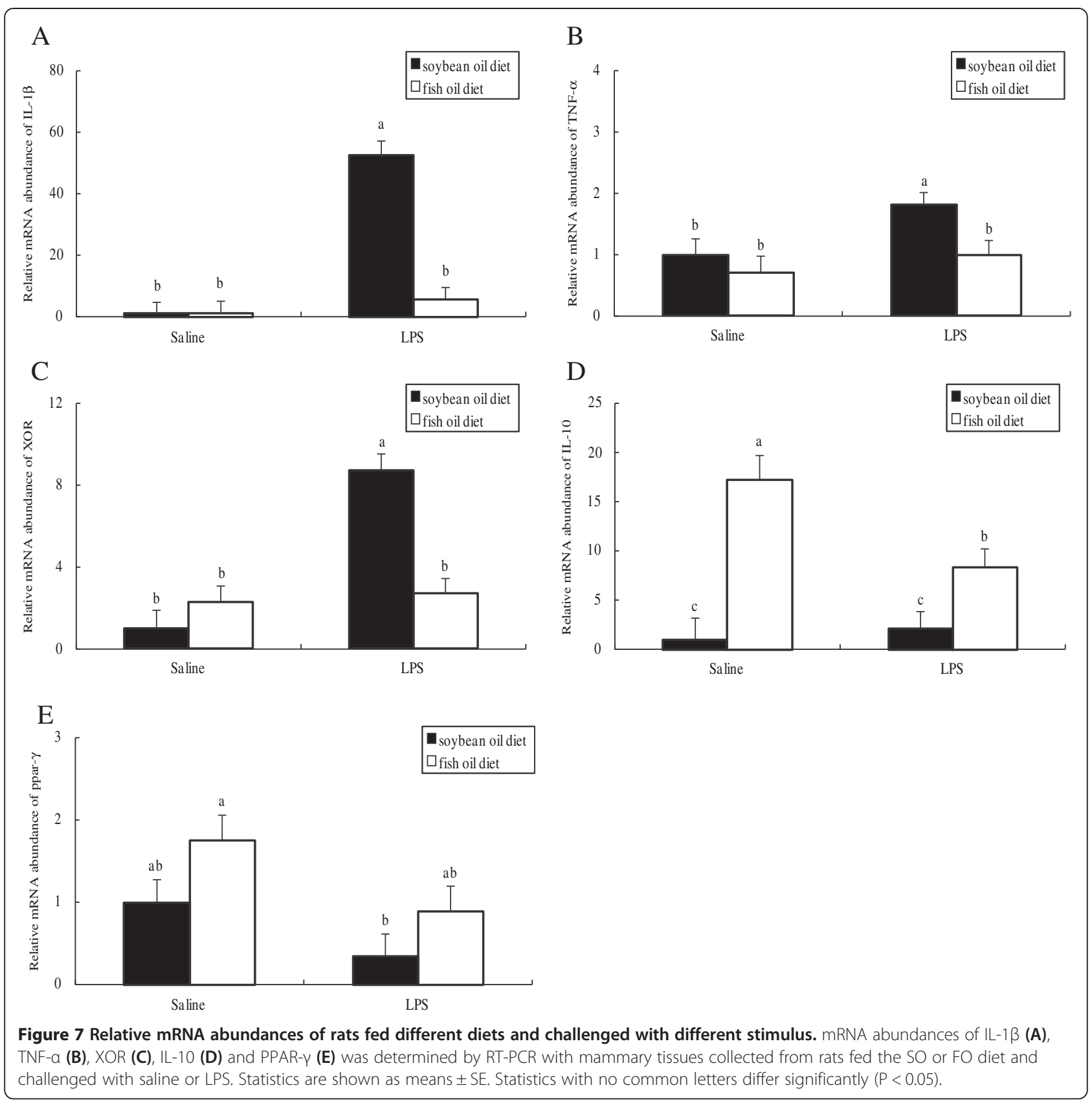

DHA specifically enhanced anti-inflammatory IL-10 secretion [34]. Moreover, it has been shown in HK-2 cells that DHA and EPA can activate the mRNA expression of PPAR- $\gamma$ [35]. Meanwhile, n-3 PUFA and their metabolites are natural ligands for PPAR- $\gamma$ [36] and DHA for example can be metabolized by oxygenase to $17-\mathrm{OH}$ and 7-OH-DHA thus facilitates PPAR- $\gamma$ activation [37]. Therefore, n-3 PUFA can upregulate PPAR- $\gamma$ expression and promote PPAR- $\gamma$ functioning. Noticeably, maternal PPAR- $\gamma$ was demonstrated to be pivotal for protecting the nursing newborns by suppressing the production of inflammatory lipids in the lactating mammary glands [38]. Additionally, it was assumed that IL-10 may inhibit the production of TNF- $\alpha$ and IL- 6 in the mammary glands [39]. Therefore, we postulated that FO might down-regulate the mRNA expression of IL- $1 \beta$, XOR and TNF- $\alpha$ through enhancing the expression of IL-10 and PPAR- $\gamma$.

\section{Conclusions}

This study suggested that mammary inflammation induced by pregnancy proceeding and pathogen challenge might be attenuated by consumption of FO rich in n-3 


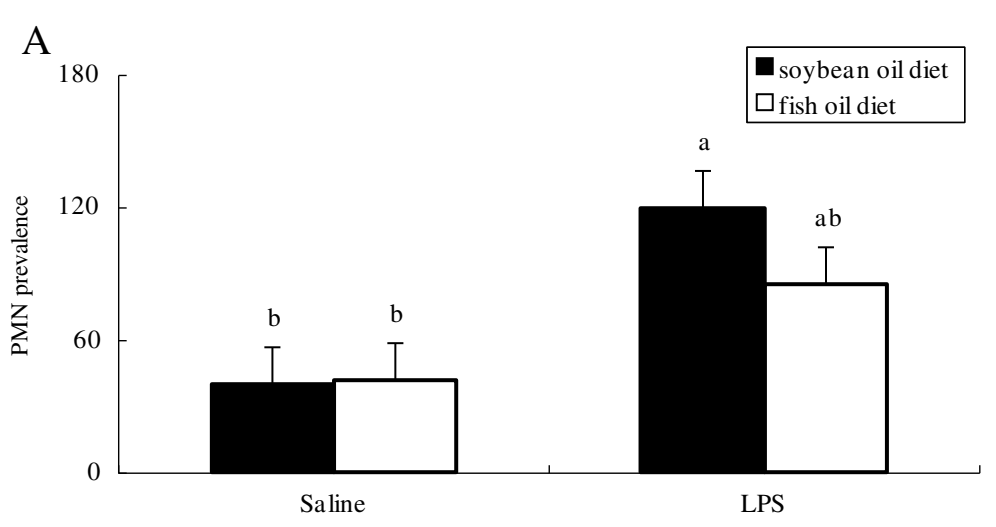

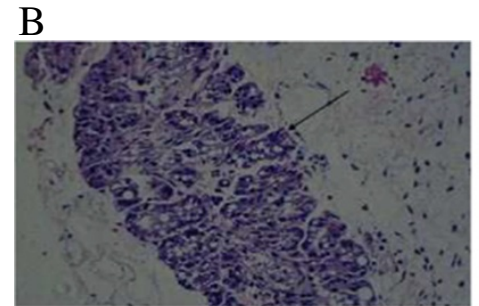

Saline

Soybean oil

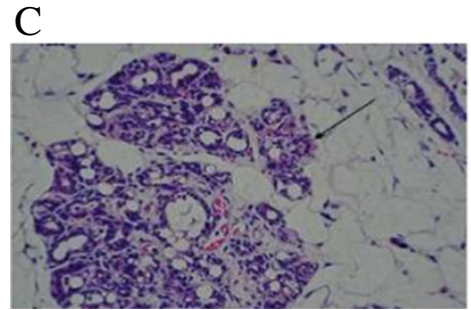

Saline

Fish oil

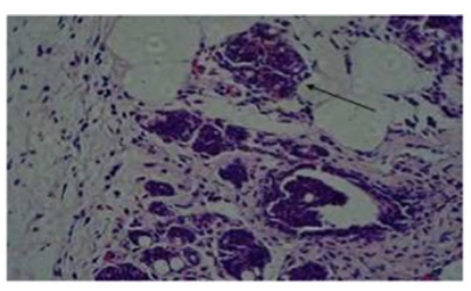

LPS

Soybean oil

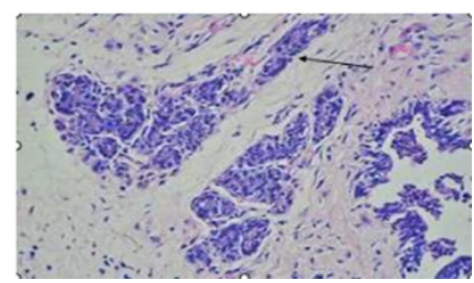

LPS

Figure 8 Histopathology of mammary glands of rats fed different diets and challenged with different stimulus. Hematoxylin and eosin stained slides were made with mammary tissues collected from rats fed the SO diet (B) or FO diet (C) and challenged with saline or LPS. PMN prevalence (A) in alveoli was estimated by using light microscopic (Olympus BH2, Japan) analysis at a magnification of 400x. Statistics are shown as means \pm SE. Statistics with no common letters differ significantly $(P<0.05)$.

PUFA. IL-10 and PPAR- $\gamma$ appeared to be the key mediators elicited by FO consumption in ameliorating the mammary inflammation.

\section{Methods}

\section{Animals, diets and treatments}

All experimental protocols were approved by the Animal Care and Use Committee of Sichuan Agricultural University, and were in accordance with the National Research Council's Guide for the Care and Use of Laboratory Animals. The experimental rats (Virgin female SpragueDawley rats) were purchased from Sichuan Academy of Medical Sciences-Sichuan Provincial People's Hospital Experimental Animal Research Institute, and housed individually in metallic cages in a temperature controlled $\left(22 \pm 2^{\circ} \mathrm{C}\right)$ room with a $12 \mathrm{~h}$ light/dark cycle and relative humidity was maintained at $60 \pm 10 \%$.

Experimental diets (Table 3 ) were formulated to meet or exceed the nutrient requirements of gestating and lactating rats as recommended by AIN-93G. To create difference in inclusion levels of dietary SFA and n-3 PUFA and to make sure the two diets were isocaloric, the $7 \mathrm{~kg}$ fat included in the experimental diets was composed of $7 \mathrm{~kg}$ soybean oil (SO) in the SO diet, and $5 \mathrm{~kg}$ fish oil (FO), $1 \mathrm{~kg}$ lard and $1 \mathrm{~kg}$ SO in the FO diet. The FA composition of the two types of oil and experimental diets is shown in Table 4. To avoid PUFA oxidation, all diets were stored at $-20 \mathrm{C}$.

At the beginning of the experiment, all female rats were housed together with male rats to complete mating. When 
Table 3 Ingredients and composition of experimental diets (air-dry basis)

\begin{tabular}{|c|c|c|c|}
\hline Ingredients & Content (\%) & Composition & Content (\%) \\
\hline Corn starch & 39.75 & Crude protein & 16.23 \\
\hline Casein & 20 & ME, Mcal/kg & 3.81 \\
\hline Gelatinization starch & 13.2 & Lysine & 1.53 \\
\hline Sucrose & 10 & Methionine & 0.57 \\
\hline Fat $^{1}$ & 7 & Calcium & 0.50 \\
\hline Fiber & 5 & $\begin{array}{l}\text { Available } \\
\text { phosphorus }\end{array}$ & 0.16 \\
\hline Mineral premix ${ }^{2}$ & 3.5 & & \\
\hline Vitamin premix ${ }^{3}$ & 1 & & \\
\hline L-cysteine & 0.3 & & \\
\hline Choline Chloride & 0.25 & & \\
\hline Total & 100 & & \\
\hline \multicolumn{4}{|c|}{$\begin{array}{l}\text { 'The } 7 \mathrm{~kg} \text { fat was composed of } 7 \mathrm{~kg} \text { SO in the SO diet, and } 5 \mathrm{~kg} \text { FO, } 1 \mathrm{~kg} \text { lard } \\
\text { and } 1 \mathrm{~kg} \text { SO in the FO diet. } \\
{ }^{2} \text { Provided per kg of diet: Calcium } 5000 \mathrm{mg} \text {, Phosphorus } 1561 \mathrm{mg} \text {, Potassium } \\
3600 \mathrm{mg} \text {, sodium } 1019 \mathrm{mg} \text {, Chlorine } 1517 \mathrm{mg} \text {, magnesium } 510 \mathrm{mg} \text {, Rion35 } \\
\mathrm{mg} \text {, Zinc } 30 \mathrm{mg} \text {, Manganese } 10 \mathrm{mg} \text {, Copper } 6 \mathrm{mg} \text {, Selenium } 0.15 \mathrm{mg} \text {, } \\
\text { lodine } 0.2 \mathrm{mg} \text {. } \\
{ }^{3} \text { Provided per kg of diet: Vitamin A } 4000 \mathrm{IU} \text {, Vitamin } \mathrm{D}_{3} 1000 \mathrm{IU} \text {, Vitamin } \mathrm{K}_{3} \\
0.75 \mathrm{mg} \text {, Vitamin } \mathrm{B}_{1} 6.0 \mathrm{mg} \text {, Vitamin } \mathrm{B}_{2} 7.0 \mathrm{mg} \text {, Vitamin } \mathrm{B}_{6} 6.0 \mathrm{mg} \text {, Vitamin } \mathrm{B}_{12} \\
0.02 \mathrm{mg} \text {, nicotinic acid } 30.0 \mathrm{mg} \text {, D-calcium pantothenate } 15.3 \mathrm{mg} \text {, folic acid } \\
2.0 \mathrm{mg} \text {, biotin } 0.2 \mathrm{mg} \text {. }\end{array}$} \\
\hline
\end{tabular}

seminal plug in the vagina was detected in the morning, then that day was designated as day 0 of gestation. Forty-eight rats after mating were housed individually and began to receive the SO or FO diets. Blood and mammary tissue samples $(n=6)$ at day 0 and 14 of gestation and day 3 postpartum, respectively, were collected 9 hours after intramammary infusion of LPS according to the work of Miao et al [40]. The infusion was conducted according to the methods of Zhong et al [41]. Briefly, the inguinal mammary glands of rats were infused with 0 or $10 \mu \mathrm{g}$ E.coli LPS (O55:B5, Sigma, USA) dissolved in $100 \mu \mathrm{l}$ sterile, pyrogen-free, physiological saline. Blood samples were collected (after 12-h fast and following isoflurane anesthesia) through intraorbital bleeding for the separation of plasma and then stored at $-20^{\circ} \mathrm{C}$ until analysis. The fourth mammary glands were cut with scissors, and then the left and right mammary glands were snap frozen in lipid nitrogen and stored at $-80^{\circ} \mathrm{C}$ or fixed in $4 \%$ paraformaldehyde and stored at $4^{\circ} \mathrm{C}$ respectively.

\section{FA composition analysis}

Plasma FA composition was determined according to the methods described by Fernández-Real et al [42] with modification. In brief, 30-50 mg weighed plasma sample was mixed with four milliliter acetyl chloride and methanol solution (1:10, vol/vol). Transesterification was conducted and the pooled solvent extracts were dried by
Table 4 FA composition of oil $(\mathrm{g} / 100 \mathrm{~g})$ and diets $(\mathrm{g} / \mathrm{kg})$ (as fed basis)

\begin{tabular}{|c|c|c|c|c|}
\hline Fatty acids & SO & FO & SO diet & FO diet \\
\hline $\mathrm{C} 14: 0$ & 0.05 & 0.92 & 0.09 & 0.39 \\
\hline C16:0 & 10.93 & 9.05 & 5.25 & 5.49 \\
\hline C18:0 & 2.25 & 1.60 & 2.03 & 2.05 \\
\hline C20:0 & 0.02 & 0.12 & 0.20 & 0.07 \\
\hline C16:1 & 0.09 & 6.14 & 0.06 & 2.00 \\
\hline C18:1 & 27.43 & 23.00 & 11.72 & 10.77 \\
\hline C20:1 & 0.03 & 3.06 & 0.22 & 1.04 \\
\hline C22:1 & $N^{1}$ & 2.31 & 0.23 & 0.78 \\
\hline C18:2n6 & 52.00 & 2.27 & 22.54 & 4.67 \\
\hline C18:3n3 & 5.80 & 1.49 & 2.18 & 0.68 \\
\hline C20:5n3 & ND & 21.90 & 0.225 & 4.48 \\
\hline C22:6n3 & ND & 14.60 & ND & 2.84 \\
\hline Other & 1.40 & 13.54 & 0.26 & 2.76 \\
\hline$\sum F A^{2}$ & 100 & 100 & 45 & 38 \\
\hline$\sum \mathrm{SFA}^{3}$ & 13.25 & 11.69 & 7.57 & 8.00 \\
\hline$\sum M U F A{ }^{4}$ & 27.55 & 34.51 & 12.23 & 14.58 \\
\hline$\sum$ PUFA $^{5}$ & 57.80 & 40.26 & 24.94 & 12.66 \\
\hline$\Sigma \mathrm{SFA} / \Sigma \mathrm{FA}$ & 13.25 & 11.69 & 16.82 & 21.05 \\
\hline$\sum M U F A / \Sigma F A$ & 27.55 & 34.51 & 27.18 & 38.37 \\
\hline$\sum P U F A / \Sigma F A$ & 57.80 & 40.26 & 55.43 & 33.32 \\
\hline$\sum n-3^{6}$ & 5.8 & 37.99 & 2.41 & 7.99 \\
\hline$\sum n-6^{7}$ & 52 & 2.27 & 22.54 & 4.67 \\
\hline$\sum n-6 / \sum n-3$ & 8.97 & 0.06 & 9.36 & 0.58 \\
\hline
\end{tabular}

${ }^{1} \mathrm{ND}$, Not detected.

${ }^{2} \sum F A$ means the sum of content of all fatty acids evaluated.

${ }^{3} \Sigma$ SFA means the sum of $\mathrm{C} 14: 0, \mathrm{C} 16: 0, \mathrm{C} 18: 0$ and $\mathrm{C} 20: 0$ content.

${ }^{4} \Sigma$ MUFA means the sum of $C 16: 1, C 18: 1, C 20: 1$ and $C 22: 1$ content.

${ }^{5} \sum$ PUFA means the sum of $C 18: 2 n 6, C 18: 3 n 3, C 20: 5 n 3$ and $C 22: 6 n 3$ content

${ }^{6} \Sigma \mathrm{n}-3$ means the sum of $\mathrm{C} 18: 3 \mathrm{n} 3, \mathrm{C} 20: 5 \mathrm{n} 3$ and $\mathrm{C} 22: 6 \mathrm{n} 3$ content.

${ }^{7} \Sigma n-6$ means the content of $C 18: 2 n 6$.

nitrogen at room temperature. The residues were dissolved in $5 \mathrm{ml}$ hexane with internal standard and subjected to water bath at $80^{\circ} \mathrm{C}$ for 2 hours. Then $7 \%$ potassium carbonate was added, and supernatant was collected for analysis. Hewlett-Packard 6890 gas chromatograph equipped with a flame ionization detector was used to analyze the FA composition, and helium was used as carrier gas. The injector temperature was programmed at $250^{\circ} \mathrm{C}$ and the detector temperature was $270^{\circ} \mathrm{C}$.

\section{FFA analysis}

A commercial ELISA kit (GBD, USA) was used to determine plasma free fatty acids (FFA) concentration as described by the manufacturer's protocols. All assays were conducted in 96-well plates and absorbance at $450 \mathrm{~nm}$ was detected with a microplate reader. FFA values were 
calculated according to the standard curve generated from the corresponding absorbance of the standard reagent.

\section{RNA extraction and real-time PCR}

The mRNA abundances of the mammary gland samples were measured by real-time polymerase chain reaction (PCR) as previously described [43]. Total RNA was extracted using a TRIZOL Reagent kit (Invitrogen, Carlsbad, CA). The cDNA was prepared using a reverse transcription (RT) kit (TAKARA, Japan) following the manufacture's instruction. Primers were synthesized by Chengdu Tiantai Biological Company (Chengdu, China). Beta-actin was used as an internal control according to the work of $\mathrm{Gu}$ et al [43]. The nucleotide primer sequences are listed in Table 5. Quantitative real-time RT-PCR analysis was performed using a 7900 real-time PCR system (Applied Biosystems, USA) and SYBR Green assays (Master Mix SYBR ${ }^{\circ}$ Green TAKARA, Japan). The specificity of PCR products were examined with melting curve analysis. Results (fold changes) were expressed as $2^{-\Delta \Delta C t}$ with $\Delta \Delta \mathrm{Ct}=(\mathrm{Ct}$ ij-Ct $\beta$-actin $\mathrm{j})-(\mathrm{Ct}$ i1 $\mathrm{Ct} \beta$-actin1), where $\mathrm{Ct}$ ij and $\mathrm{Ct} \beta$-actin $\mathrm{j}$ are the $\mathrm{Ct}$ for gene $i$ and for $\beta$-actin in a sample (named $j$ ), and where $\mathrm{Ct} \mathrm{i} 1$ and $\mathrm{Ct} \beta$-actin1 are the $\mathrm{Ct}$ in sample 1, expressed as the standard.

\section{Histopathologic examination}

Mammary tissue samples fixed in 4\% paraformaldehyde for $24 \mathrm{~h}$ were further processed with standard dehydration and paraffin-wax embedding procedures to produce tissue blocks. Hematoxylin and eosin stained slides were made as described previously [40]. The prevalence of polymorphonuclear neutrophils (PMN) in alveoli was estimated by using light microscopic (Olympus BH2, Japan) analyses at a magnification of $400 \times$ as previously described [40]. Briefly, four sections of mammary tissues were chosen for each rat. Ten fields were randomly selected per sample. Results were presented as average PMN infiltration scores for each time point.

\section{Immunohistochemistry}

Polyclonal antibodies combined with the avidinbiotinperoxidase complex $(\mathrm{ABC})$ technique were used for the immunohistochemical detection of interleukin (IL)- $1 \beta$ (Abnova, USA) and tumor necrosis factor (TNF)- $\alpha$ (Novus, USA). All samples from one animal were analyzed within the same assay run, and within each assay run treatment animals to be compared were included. The quantification of IL- $1 \beta$ and TNF- $\alpha$ protein expression in mammary tissue samples was performed as described [44]. For each sample, a relative value of the amount of cytokine produced was expressed as the average percentage of the positively stained areas.

\section{Statistic analysis}

All statistical evaluation was performed by using the General Linear Model procedures of SAS statistical package (V8.1, SAS Institute Inc., Cary, NC). The statistic model used is as follows: $Y_{i j k}=\mu+A_{i}+B_{j}+(A \times B)_{i j}+\varepsilon_{i j k}$, where $Y$ is the analysed variable, $\mu$ the overall mean, $A$ the effect of diet, $B$ the effect of time or LPS, $A \times B$ the effect of diet $\times$ time or LPS interaction, and $\varepsilon$ the random error. Least-squares means comparison was used to evaluate differences among treatments. $P$ values $\leq 0.05$ were considered statistical significance.

Table 5 PCR product sequences of oligonucleotide primers used to amplify cytokines and a house keeping gene

\begin{tabular}{|c|c|c|c|c|}
\hline Gene & & Primer sequences $\left(5^{\prime}-3^{\prime}\right)$ & Products size & Genebank accession number \\
\hline \multirow[t]{2}{*}{ IL-1 $\beta$} & Forward & tgacctgttctttgaggctgac & $113 \mathrm{bp}$ & M98820.1 \\
\hline & Reverse & cgagatgctgctgtgagatttg & & \\
\hline \multirow[t]{2}{*}{ TNF-a } & Forward & ccactctgacccctttactctga & $154 \mathrm{bp}$ & NM_013693.2 \\
\hline & Reverse & ctgtcccagcatcttgtgtttc & & \\
\hline \multirow[t]{2}{*}{ IL-8 } & Forward & ccagcaggaaaccagaagaaag & $123 \mathrm{bp}$ & NM_001173399.2 \\
\hline & Reverse & caactttgtcacgaccataccc & & \\
\hline \multirow[t]{2}{*}{ IL-10 } & Forward & gctggacaacatactgctgaca & $112 \mathrm{bp}$ & NM_012854.2 \\
\hline & Reverse & ctggggcatcacttctaccag & & \\
\hline \multirow[t]{2}{*}{ PPAR- $\gamma$} & Forward & gccctttggtgactttatggag & $170 \mathrm{bp}$ & NM_013124.3 \\
\hline & Reverse & gcagcaggttgtcttggatgt & & \\
\hline \multirow[t]{2}{*}{ XOR } & Forward & gattctcacacacctcctgacg & $156 \mathrm{bp}$ & NM_011723.2 \\
\hline & Reverse & ccccacacacacacacacactat & & \\
\hline \multirow[t]{2}{*}{$\beta$-actin } & Forward & ctgtgtggattggtggctctatc & $133 \mathrm{bp}$ & NM_031144.2 \\
\hline & Reverse & gctcagtaacagtccgcctagaa & & \\
\hline
\end{tabular}




\section{Competing interests}

The authors declare that they have no competing interests.

\section{Authors' contributions}

ZF, DW, DC and KZ designed the research; JH, FX, SL, XZ, LC, YL, SX, GT, QZ and BY performed the research; SL, ZF, JH and FX analyzed the data and wrote the paper. All authors read and approved the final manuscript.

\section{Acknowledgments}

The work was supported by the National Natural Science Fundation of China (30901042), Sichuan Province Science Foundation for Fostering Youths Talents (2011JQ0015), Key Program Fundation of the Education Department of Sichuan Province, and Novus Research Fellowship (NRF).

Received: 11 November 2013 Accepted: 26 December 2013 Published: 31 December 2013

\section{References}

1. Santman-Berends IM, Olde Riekerink RG, Sampimon OC, van Schaik G, Lam TJ: Incidence of subclinical mastitis in Dutch dairy heifers in the first 100 days in lactation and associated risk factors. J Dairy Sci 2012, 95:2476-2484.

2. Akers RM, Nickerson SC: Mastitis and its impact on structure and function in the ruminant mammary gland. J Mammary Gland Biol Neoplasia 2011, 16:275-289.

3. Gerjets I, Traulsen I, Reiners K, Kemper N: Assessing individual sow risk factors for coliform mastitis: a case-control study. Prev Vet Med 2011, 100:248-251.

4. Sordillo LM: New concepts in the causes and control of mastitis. J Mammary Gland Biol Neoplasia 2011, 16:271-273.

5. Deluyker HA, Van Oye SN, Boucher JF: Factors affecting cure and somatic cell count after pirlimycin treatment of subclinical mastitis in lactating cows. J Dairy Sci 2005, 88:604-614.

6. Gerjets I, Kemper N: Coliform mastitis in sows: a review. J Swine Health Prod 2009, 17:97-105.

7. Porcherie A, Cunha P, Trotereau A, Roussel P, Gilbert FB, Rainard P, Germon P: Repertoire of Escherichia coli agonists sensed by innate immunity receptors of the bovine udder and mammary epithelial cells. Vet Res 2012, 43:14.

8. Chen $\mathrm{H}, \mathrm{Mo} X, \mathrm{Yu}$ J, Huang $\mathrm{Z}$ : Alpinetin attenuates inflammatory responses by interfering toll-like receptor 4/nuclear factor kappa B signaling pathway in lipopolysaccharide-induced mastitis in mice. Int Immunopharmacol 2013, 17:26-32.

9. Wong SW, Kwon MJ, Choi AMK, Kim HP, Nakahira K, Hwang DH: Fatty acids modulate toll-like receptor 4 activation through regulation of receptor dimerization and recruitment into lipid rafts in a reactive oxygen species-dependent manner. J Biol Chem 2009, 284:27384-27392.

10. Schwartz EA, Zhang WY, Karnik SK, Borwege S, Anand VR, Laine PS, Su Y, Reaven PD: Nutrient modification of the innate immune response: a novel mechanism by which saturated fatty acids greatly amplify monocyte inflammation. Arterioscler Thromb Vasc Biol 2010, 30:802-808.

11. Du Y, Yang M, Lee S, Behrendt CL, Hooper LV, Saghatelian A, Wan Y: Maternal western diet causes inflammatory milk and TLR2/4-dependent neonatal toxicity. Genes Dev 2012, 26:1306-1311.

12. Liu Y, Chen F, Odle J, Lin X, Zhu H, Shi H, Hou Y, Yin J: Fish oil increases muscle protein mass and modulates Akt/FOXO, TLR4, and NOD signaling in weanling piglets after lipopolysaccharide challenge. J Nutr 2013, 143:1331-1339.

13. Kris-Etherton PM: Fish consumption, fish oil, omega-3 fatty acids, and cardiovascular disease. Circulation 2002, 106:2747-2757.

14. Wang $C$, Harris WS, Chung M, Lichtenstein AH, Balk EM, Kupelnick B, Jordan HS, Lau J: n-3 Fatty acids from fish or fish-oil supplements, but not alpha-linolenic acid, benefit cardiovascular disease outcomes in primary- and secondary-prevention studies: a systematic review. Am J Clin Nutr 2006, 84:5-17.

15. Herold PM, Kinsella JE: Fish oil consumption and decreased risk of cardiovascular disease: a comparison of findings from animal and human feeding trials. Am J Clin Nutr 1986, 43:566-598.

16. Lo C-J, Chiu KC, Fu M, Lo R, Helton S: Fish oil decreases macrophage tumor necrosis factor gene transcription by altering the NFKB activity. J Surg Res 1999, 82:216-221.
17. Novak TE, Babcock TA, Jho DH, Helton WS, Espat NJ: NF-kB inhibition by $\omega$-3 fatty acids modulates LPS-stimulated macrophage TNF-a transcription. Am J Physiol Lung Cell Mol Physiol 2003, 284:L84-L89.

18. Khalfoun B, Thibault F, Watier H, Bardos P, Lebranchu Y: Docosahexaenoic and eicosapentaenoic acids inhibit in vitro human endothelial cell production of interleukin-6. Adv Exp Med Biol 1996, 400:589-597.

19. Hall JA, Saun RJ, Wander RC: Dietary $(n-3)$ fatty acids from menhaden fish oil alter plasma fatty acids and leukotriene B synthesis in healthy horses. J Vet Intern Med 2004, 18:871-879.

20. Amira A, Zuki A, Goh Y, Noordin M, Ebrahimi M: Effects of varying levels of n-6: $n-3$ fatty acid ratio on plasma fatty acid composition and prostanoid synthesis in pregnant rats. Afr J Biotechnol 2010, 9:8881-8888.

21. Hunt KM, Williams JE, Shafii B, Hunt MK, Behre R, Ting R, McGuire MK, McGuire MA: Mastitis is associated with increased free fatty acids, somatic cell count, and interleukin-8 concentrations in human milk. Breastfeed Med 2013, 8:105-110.

22. Aggarwal BB, Shishodia S, Sandur SK, Pandey MK, Sethi G: Inflammation and cancer: how hot is the link? Biochem Pharmacol 2006, 72:1605-1621.

23. Dinarello CA: Proinflammatory cytokines. Chest 2000, 118:503-508.

24. Oviedo-Boyso J, Valdez-Alarcón JJ, Cajero-Juárez M, Ochoa-Zarzosa A, López-Meza JE, Bravo-Patino A, Baizabal-Aguirre VM: Innate immune response of bovine mammary gland to pathogenic bacteria responsible for mastitis. J Infect 2007, 54:399-409.

25. Martin HM, Hancock JT, Salisbury V, Harrison R: Role of xanthine oxidoreductase as an antimicrobial agent. Infect Immun 2004, 72:4933-4939.

26. Subbaramaiah K, Howe LR, Bhardwaj P, Du B, Gravaghi C, Yantiss RK, Zhou XK, Blaho VA, Hla T, Yang P: Obesity is associated with inflammation and elevated aromatase expression in the mouse mammary gland. Cancer Prev Res (Phila) 2011, 4:329-346.

27. Fiorentino DF, Zlotnik A, Mosmann T, Howard M, O'garra A: IL-10 inhibits cytokine production by activated macrophages. J Immunol 1991, 147:3815-3822.

28. Jiang C, Ting AT, Seed B: PPAR- $\gamma$ agonists inhibit production of monocyte inflammatory cytokines. Nature 1998, 391:82-86.

29. Endres S, Ghorbani R, Kelley VE, Georgilis K, Lonnemann G, van der Meer JW, Cannon JG, Rogers TS, Klempner MS, Weber PC, et al: The effect of dietary supplementation with $n-3$ polyunsaturated fatty acids on the synthesis of interleukin-1 and tumor necrosis factor by mononuclear cells. N Engl J Med 1989, 320:265-271.

30. Lublin A, Wolfenson D: Lactation and pregnancy effects on blood flow to mammary and reproductive systems in heat-stressed rabbits. Comp Biochem Physiol A Physiol 1996, 115:277-285.

31. Akira S, Uematsu $S$, Takeuchi O: Pathogen recognition and innate immunity. Cell 2006, 124:783-801.

32. Appel S, Mirakaj V, Bringmann A, Weck MM, Grünebach F, Brossart P: PPAR- $\gamma$ agonists inhibit toll-like receptor-mediated activation of dendritic cells via the MAP kinase and NF-kB pathways. Blood 2005, 106:3888-3894.

33. Liu B-S, Groothuismink ZM, Janssen HL, Boonstra A: Role for IL-10 in inducing functional impairment of monocytes upon TLR4 ligation in patients with chronic HCV infections. J Leukoc Biol 2011, 89:981-988.

34. Oliver E, McGillicuddy FC, Harford KA, Reynolds CM, Phillips CM, Ferguson JF, Roche HM: Docosahexaenoic acid attenuates macrophage-induced inflammation and improves insulin sensitivity in adipocytes-specific differential effects between LC n-3 PUFA. J Nutr Biochem 2012, 23:1192-1200.

35. Li H, Ruan XZ, Powis SH, Fernando R, Mon WY, Wheeler DC, Moorhead JF, Varghese Z: EPA and DHA reduce LPS-induced inflammation responses in HK-2 cells: evidence for a PPAR-gamma-dependent mechanism. Kidney Int 2005, 67:867-874.

36. Edwards IJ, O'Flaherty JT: Omega-3 Fatty Acids and PPARgamma in Cancer. PPAR Res 2008, 2008:358052-358052.

37. González-Périz A, Planagumà A, Gronert K, Miquel R, López-Parra M, Titos E, Horrillo R, Ferré N, Deulofeu R, Arroyo V: Docosahexaenoic acid (DHA) blunts liver injury by conversion to protective lipid mediators: protectin D1 and 17S-hydroxy-DHA. FASEB J 2006, 20:2537-2539.

38. Wan Y, Saghatelian A, Chong L-W, Zhang C-L, Cravatt BF, Evans RM: Maternal PPARY protects nursing neonates by suppressing the production of inflammatory milk. Genes Dev 2007, 21:1895-1908.

39. Goldman AS, Chheda S, Garofalo R, Schmalstieg FC: Cytokines in human milk: properties and potential effects upon the mammary gland and the neonate. J Mammary Gland Biol Neoplasia 1996, 1:251-258. 
40. Miao JF, Zhu YM, Gu BB, Wang XB, Zou SX, Deng YE: Evaluation of the changes of immune cells during lipopolysaccharide-induced mastitis in rats. Cytokine 2007, 40:135-143.

41. Zhong K: Establishment of experimental mastitis model by endotoxin via teat duct in rat. J Agric Biotechnol 2005, 13:654-658.

42. Fernandez-Real JM, Broch $M$, Vendrell J, Ricart W: Insulin resistance, inflammation, and serum fatty acid composition. Diabetes Care 2003, 26:1362-1368.

43. Gu B, Miao J, Fa Y, Lu J, Zou S: Retinoic acid attenuates lipopolysaccharideinduced inflammatory responses by suppressing TLR4/NF-KB expression in rat mammary tissue. Int Immunopharmacol 2010, 10:799-805.

44. Zhu Y, Fossum C, Berg M, Magnusson U: Morphometric analysis of proinflammatory cytokines in mammary glands of sows suggests an association between clinical mastitis and local production of IL-1beta, IL-6 and TNF-alpha. Vet Res 2007, 38:871-882.

doi:10.1186/1476-511X-12-190

Cite this article as: Lin et al:: Mammary inflammation around parturition appeared to be attenuated by consumption of fish oil rich in $n-3$ polyunsaturated fatty acids. Lipids in Health and Disease 2013 12:190.

\section{Submit your next manuscript to BioMed Central and take full advantage of:}

- Convenient online submission

- Thorough peer review

- No space constraints or color figure charges

- Immediate publication on acceptance

- Inclusion in PubMed, CAS, Scopus and Google Scholar

- Research which is freely available for redistribution 